Choi et al., Afr J Tradit Complement Altern Med., (2018) 15 (2): 26-34

https://doi.org/10.21010/ajtcam.v15i2.4

\title{
IN VITRO ANTI-INFLAMMATORY ACTIVITY OF THE COMPONENTS OF AMOMUM TSAO-KO IN MURINE MACROPHAGE RAW 264.7 CELLS
}

\section{Chun Whan Choi ${ }^{1, \#, ~ J u ~ Y o u n g ~ S h i n ~}{ }^{1, \#, \text { Changon Seo }}{ }^{1}$, Seong Su Hong ${ }^{1}$, Eun-Kyung Ahn ${ }^{1}$, Young Hoon Jung ${ }^{1}$, Joa Sub Oh ${ }^{2 *}$}

${ }^{1}$ Bio-Center, Gyeonggi Institute of Science \& Technology Promotion, Gyeonggi-do 16229, Korea. ${ }^{2}$ College of Pharmacy, Dankook University, Chungnam 31116, Korea. "These authors contributed equally to this work.

*Corresponding Author E-mail: jsoh@dankook.ac.kr

\begin{tabular}{|c|}
\hline$\underline{\text { Article History }}$ \\
Received: Nov. 22, 2016 \\
Revised Received: March. 28, 2017 \\
Accepted: March. 28, 2017 \\
Published Online: Feb. 23, 2018 \\
\hline
\end{tabular}

\begin{abstract}
Background: Plants still remain the prime source of drugs for the treatment of inflammation and can provide leads for the development of novel anti-inflammatory agents.

Material and methods: An in vitro bioassay guide revealed that the $80 \%$ ethanol (EtOH) extract of the whole plant, Aтотит tsao-ko (Zingiberaceae), displayed anti-inflammatory activity after assessing its effects on murine macrophage RAW 264.7 cells.

Result: Phytochemical study of the $80 \%$ EtOH extract of Amomum tsao-ko led to the isolation of eight compounds: 4-hydroxy-3-methoxy-benzoic acid (1), meso-hannokinol (2), (+)-hannokinol (3), coumaric acid (4), 4-hydroxy-benzoic acid (5), (+)-epicatechin (6), (-)-catechin (7), and myrciaphenone A (8). The results indicated that two of the isolated components, (+)-epicatechin (6) and (-)-catechin (7), inhibited the production of nitric oxide (NO) significantly in lipopolysaccharide treated RAW 264.7 cells.

Conclusion: LPS-induced interleukin tumor necrosis factor-alpha (TNF- $\square$ ), IL-1 $\beta$ and IL-10 production was also decreased in a dose-dependent manner. In addition, western blot analysis revealed that (+)-epicatechin (6) and (-)-catechin (7) reduced the expression of inducible nitric oxide synthase and inhibited nuclear localization of nuclear

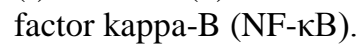

Keywords: Amomum tsao-ko, Anti-inflammatory activity, Phytochemical, Cytokines, NF-kB

\section{Introduction}

Amomum tsao-ko (A. tsao-ko) Crevost et Lemaire is a plant of the genus Amomum in the family Zingiberaceae, native to several countries Asia and Africa such as southern China, northern Viet Nam and Ethiopia. The dried fruit of A. tsao-ko used as an eliminate phlegm, warm the spleen, reduce abdominal pain, dyspepsia, and vomiting agent in Oriental traditional medicine (Lim et al., 2013; Zhao et al., 2010). Tsaokoin, a bicyclic nonane, and antioxidants, including hannokinol diarylheptanoids, have been isolated from this plant (Teresita et al., 2000). An antibacterial, spiroketal aculeatin (Moon et al., 2004), an antimalarial, diterpene peroxide (Kamchonwongpaisan et al., 1995), and eicosenones (Donga et al., 1988) have been identified from other species of the genus Amomum. Although the plant A. tsao-ko has long been used as a spice and perfume in addition to its medicinal usage, very few studies have reported its anti-inflammatory constituents (Lee et al., 2008). As a result of our ongoing search for novel bioactive natural products from medicinal plants, the $80 \%$ ethanol (EtOH) extract of the powdered fruit of $A$. tsao-ko was found to show significant anti-inflammatory activity in lipopolysaccharide (LPS)-treated RAW 264.7 cells. To investigate the anti-inflammatory properties of $A$. tsao-ko Ext. and its main components, we performed their effects on the survival and immune status of RAW 264.7 murine macrophage cells. Cell viability was determined using a MTT assay after treatment with various concentrations of the isolated constituents. Inhibition of NO production and iNOS expression were measured by reaction with Griess reagent and western blot analysis in LPS-induced RAW 264.7 cells, respectively. Constantly, we investigated the effects of compounds $6((+)$-epicatechin) and 7 ((-)-catechin) on tumor necrosis factor (TNF)- $\alpha$, IL-1 $\beta$, and IL-10, which are related to inflammatory response at both reverse 
transcription-polymerase chain reaction (RT-PCR) and enzyme-linked immunosorbent assay (ELISA). NF- $\kappa \mathrm{B}$ is known to play an important role in gene expression on inflammation (Eliopoulos et al., 2002). The present study confirmed that the inhibitory effects of (+)-epicatechin and (-)-catechin were mediated via inhibition of nuclear localization of NF- $\kappa \mathrm{B}$, which were also determined by western blot analysis.

\section{Materials and Methods General Procedures}

Ultraviolet (UV) spectra were obtained using a Shimadzu UV-1650PC spectrometer. Nuclear magnetic resonance (NMR) spectra were measured on a Bruker Advance (700MHz 54mm Asecnd shilded Magnet). Chemical shifts were expressed in terms of values. Electrospray ionization (ESI) mass spectra were obtained using a LTQ Orbitrap XL (Thermo Scientific) mass spectrometer. Preparative high performance liquid chromatography (prep-HPLC) was performed using a Shimadzu system (LC-8A pump and Diode Array Detector) and a YMC-Pack octadecyl (ODS) A column $(250 \times 20 \mathrm{~mm}$ i.d.), using a gradient solvent system of methanol $\mathrm{MeOH}-\mathrm{water}$ (0:100-100:0) at a flow rate of $8 \mathrm{~mL} / \mathrm{min}$. Medium pressure liquid chromatography (MPLC; Combi Flash RF, Teledyne ISCO) separations were performed using a RediSep Rf C18 column (50g-150 g C18 Reverse Phase with a flow rate of 40mL-85 mL/min). Open column chromatography was performed using silica gel (Kieselgel 60, $70-230$ mesh Merck) and thin layer chromatography (TLC) was performed using pre-coated silica gel 60 F254 (0.25 mm, Merck).

\section{Plant Material}

Dried A. tsao-ko was purchased from the Kyungdong Oriental Herbal Market in Korea (August 2012) and identified by one of the authors (Prof. Joa Sub Oh). A voucher specimen (G47) was deposited at the Natural Products Research Laboratory, Gyeonggido Business and Science Accelerator.

\section{Extraction and Isolation}

Dried A. tsao-ko $(9.6 \mathrm{~kg})$ was extracted with $5 \mathrm{~L}$ of $80 \% \mathrm{EtOH}$ at room temperature for 5 days. After filtration with a cotton ball, the filtrate was combined and evaporated to dryness to give $538.5 \mathrm{~g}$ of dark syrupy extract, which was suspended in water $(10 \mathrm{~L})$ and partitioned with equal volumes of dichloromethane $\left(\mathrm{CH}_{2} \mathrm{Cl}_{2}\right)$, ethylacetate (EtOAc), and $n$-butanol $\left(n\right.$-BuOH) successively to give a $\mathrm{CH}_{2} \mathrm{Cl}_{2}$ soluble fraction $(146 \mathrm{~g})$, an EtOAc soluble fraction $(33.5 \mathrm{~g})$, a $n$-BuOH soluble fraction $(85 \mathrm{~g})$, and a residual aqueous fraction $(267 \mathrm{~g})$. The EtOAc soluble fraction (33.5 g) was subjected to silica gel column $(\varnothing=5.0 \times 100 \mathrm{~cm})$ chromatography and eluted with $\mathrm{MeOH}$ in $\mathrm{CH}_{2} \mathrm{Cl}_{2}$ in a step-gradient manner (1\% to 50\%) to afford seven fractions (F1: 1.7 g, F2: 0.98 g, F3: 2.6 g, F4: 2.4 g, F5: 4.0 g, F6: $4.0 \mathrm{~g}$, and F7: $17.5 \mathrm{~g})$. The fraction F2 $(0.98 \mathrm{~g})$ was further purified using ODS column $(\varnothing=1.0 \times 80 \mathrm{~cm})$ chromatography to give $18.8 \mathrm{mg}$ of $\mathbf{1}$. Fraction F3 $(2.4 \mathrm{~g})$ was also purified by silica gel column chromatography eluted with $\mathrm{MeOH}$ in $\mathrm{CH}_{2} \mathrm{Cl}_{2}(1 \%$ to $50 \%)$ in a stepwise gradient manner to produce five fractions (F31-F35). F32 was further purified using RP-18 column chromatography to produce $5.6 \mathrm{mg}$ of $\mathbf{2}$ and $7.3 \mathrm{mg}$ of $\mathbf{3}$. F4 (2.4 g) was purified with RP-18 column chromatography to produce $16.1 \mathrm{mg}$ of compound 4 and $27.7 \mathrm{mg}$ of $\mathbf{5}$. F5 (4.0 g) was purified with RP-18 column chromatography to produce $9.4 \mathrm{mg}$ of $\mathbf{6}$ and $10.4 \mathrm{mg}$ of 7. Repeated RP-18 chromatography of F6 (4.0 $\mathrm{g}$ ) with step-gradient elution of $\mathrm{MeOH}$ in water resulted in the purification of $4.3 \mathrm{mg}$ of $\mathbf{8}$.

Compound 1 - white amorphous powder; EI-MS m/z: $168[\mathrm{M}]^{+} ;{ }^{1} \mathrm{H}-\mathrm{NMR}\left(700 \mathrm{MHz}, \mathrm{MeOH}-d_{4}\right): \delta 7.58(1 \mathrm{H}, \mathrm{d}, J=1.2$ $\mathrm{Hz}, \mathrm{H}-3), 7.57$ (1H, dd, $J=1.8$ \& $7.5 \mathrm{~Hz}, \mathrm{H}-5), 6.85(1 \mathrm{H}, \mathrm{d}, J=7.5 \mathrm{~Hz}, \mathrm{H}-6), 3.91(3 \mathrm{H}, \mathrm{s}, \mathrm{OCH} 3) ;{ }^{13} \mathrm{C}-\mathrm{NMR}(175 \mathrm{MHz}$, $\left.\mathrm{MeOH}-d_{4}\right): \delta 168.9(\mathrm{C}-7), 151.1$ (C-1), 147.2 (C-2), 123.8 (C-5), 122.0 (C-4), 114.4 (C-3), 112.4 (C-6), 55.0 (C-OMe). Compound 2 - white amorphous powder; ESI-MS m/z: $317[\mathrm{M}+\mathrm{H}]^{+} ;{ }^{1} \mathrm{H}-\mathrm{NMR}\left(700 \mathrm{MHz}, \mathrm{MeOH}-d_{4}\right): \delta 6.99(4 \mathrm{H}, \mathrm{d}, J$ = 8.4 Hz, H-2', H-6', H-2", H-6"), 6.67 (4H, d, J = 8.4 Hz, H-3', H-5', H-3", H-5"), 3.78 (2H, m, H-3, H-5), 2.68-2.50 $\left(4 \mathrm{H}, \mathrm{m}, \mathrm{H}_{2}-1, \mathrm{H}_{2}-7\right), 1.69-1.63\left(4 \mathrm{H}, \mathrm{m}, \mathrm{H}_{2}-2, \mathrm{H}_{2}-6\right), 1.53\left(2 \mathrm{H}, \mathrm{dd}, J=6.5 \& 5.8 \mathrm{~Hz}, \mathrm{H}_{2}-4\right) ;{ }^{13} \mathrm{C}-\mathrm{NMR}(175 \mathrm{MHz}$, $\left.\mathrm{MeOH}-d_{4}\right): \delta 32.2(\mathrm{C}-1), 41.4(\mathrm{C}-2), 68.7$ (C-3), 45.6 (C-4), 68.7 (C-5), $41.4(\mathrm{C}-6) .32 .2(\mathrm{C}-7), 134.5\left(\mathrm{C}-1^{\prime}\right), 130.3$ (C-2'), 116.1 (C-3'), 156.3 (C-4'), 116.1 (C-5'), 130.3 (C-6'), 134.5 (C-1"), 130.3 (C-2"), 116.1 (C-3"), 156.3 (C-4"), 116.1 (C-5"), 130.3 (C-6").

Compound 3 - white amorphous powder; ESI-MS m/z: $317[\mathrm{M}+\mathrm{H}]^{+} ;{ }^{1} \mathrm{H}-\mathrm{NMR}\left(700 \mathrm{MHz}, \mathrm{MeOH}-d_{4}\right): \delta 6.99(4 \mathrm{H}, \mathrm{d}, J$ $=8.4$ Hz, H-2', H-6', H-2", H-6"), 6.67 (4H, d, J = 8.4 Hz, H-3', H-5', H-3", H-5"), 3.74 (2H, m, H-3, H-5), 2.63-2.52 $\left(4 \mathrm{H}, \mathrm{m}, \mathrm{H}_{2}-1, \mathrm{H}_{2}-7\right), 1.66-1.70\left(4 \mathrm{H}, \mathrm{m}, \mathrm{H}_{2}-2, \mathrm{H}_{2}-6\right), 1.60(2 \mathrm{H}, \mathrm{dd}, J=6.5 \& 5.8 \mathrm{~Hz}, \mathrm{H} 2-4) ;{ }^{13} \mathrm{C}-\mathrm{NMR}(175 \mathrm{MHz}$, $\left.\mathrm{MeOH}-d_{4}\right): \delta 30.5(\mathrm{C}-1), 39.5(\mathrm{C}-2), 69.5$ (C-3), 43.4 (C-4), 69.5 (C-5), 39.5 (C-6). 30.5 (C-7), $133.0(\mathrm{C}-1$ '), 128.9 (C-2'), 114.7 (C-3'), 154.9 (C-4'), 114.7 (C-5'), 128.9 (C-6'), 133.0 (C-1"), 128.9 (C-2"), 114.7 (C-3"), 154.9 (C-4"), 114.7 (C-5"), 128.9 (C-6").

Compound 4 - white amorphous powder; EI-MS m/z: $164[\mathrm{M}]^{+} ;{ }^{1} \mathrm{H}-\mathrm{NMR}(700 \mathrm{MHz}, \mathrm{MeOH}-d 4): \delta 7.57(1 \mathrm{H}, \mathrm{d}, J=$ $15.8 \mathrm{~Hz}, \mathrm{H}-7), 7.44(2 \mathrm{H}, \mathrm{d}, J=8.5 \mathrm{~Hz}, \mathrm{H}-3$ \& 5), $6.80(2 \mathrm{H}, \mathrm{d}, J=8.5 \mathrm{~Hz}, \mathrm{H}-2$ \& 6), $6.29(1 \mathrm{H}, \mathrm{d}, J=15.8 \mathrm{~Hz}, \mathrm{H}-8)$; ${ }^{13} \mathrm{C}-\mathrm{NMR}\left(175 \mathrm{MHz}, \mathrm{MeOH}-d_{4}\right): \delta 159.7$ (C-1), 115.4 (C-2), 129.6 (C-3), $126.0(\mathrm{C}-4), 129.6(\mathrm{C}-5), 115.4$ (C-6), 144.8 (C-7), 115.1 (C-8), 171.5 (C-9).

Compound 5 - white amorphous powder; EI-MS $m / z: 138[\mathrm{M}]^{+} ;{ }^{1} \mathrm{H}-\mathrm{NMR}\left(700 \mathrm{MHz}, \mathrm{MeOH}-d_{4}\right): \delta 7.87(2 \mathrm{H}, \mathrm{d}, J=8.8$ Hz, H-3 \& 5), 6.82 (2H, d, $J=8.8 \mathrm{~Hz}, \mathrm{H}-2$ \& 6), 6.80 (2H, d, $J=8.5 \mathrm{~Hz}, \mathrm{H}-2$ \& 6), $6.29(1 \mathrm{H}, \mathrm{d}, J=15.8 \mathrm{~Hz}, \mathrm{H}-8)$; 
${ }^{13} \mathrm{C}-\mathrm{NMR}\left(175 \mathrm{MHz}, \mathrm{MeOH}-d_{4}\right): \delta 162.0(\mathrm{C}-1), 114.6(\mathrm{C}-2), 131.6(\mathrm{C}-3), 121.4(\mathrm{C}-4), 131.6(\mathrm{C}-5), 114.6$ (C-6), 168.7 (C-7).

Compound 6 - white amorphous powder; EI-MS m/z: $290[\mathrm{M}]^{+}$; ${ }^{1} \mathrm{H}-\mathrm{NMR}\left(700 \mathrm{MHz}, \mathrm{MeOH}-d_{4}\right): \delta 7.00(1 \mathrm{H}, \mathrm{d}, J=1.9$ $\left.\mathrm{Hz}, \mathrm{H}-2^{\prime}\right), 6.82\left(1 \mathrm{H}, \mathrm{d}, J=1.9 \mathrm{~Hz} \& 8.1 \mathrm{~Hz}, \mathrm{H}-6^{\prime}\right), 6.78\left(1 \mathrm{H}, \mathrm{d}, J=8.1 \mathrm{~Hz}, \mathrm{H}-5^{\prime}\right), 5.96(1 \mathrm{H}, \mathrm{d}, J=2.1 \mathrm{~Hz}, \mathrm{H}-6), 5.94$ $(1 \mathrm{H}, \mathrm{d}, J=2.1 \mathrm{~Hz}, \mathrm{H}-8), 4.84(1 \mathrm{H}, \mathrm{s}, \mathrm{H}-2), 4.20(1 \mathrm{H}, \mathrm{m}, \mathrm{H}-3), 2.89(1 \mathrm{H}, \mathrm{dd}, J=4.63 \& 16.6 \mathrm{~Hz}, \mathrm{H}-4 \mathrm{a}), 2.76(1 \mathrm{H}, \mathrm{dd}, J$ $=2.93 \& 16.6 \mathrm{~Hz}, \mathrm{H}-4 \mathrm{~b}) ;{ }^{13} \mathrm{C}-\mathrm{NMR}\left(175 \mathrm{MHz}, \mathrm{MeOH}-d_{4}\right): \delta 78.5(\mathrm{C}-2), 66.1(\mathrm{C}-3), 27.9(\mathrm{C}-4), 156.6(\mathrm{C}-5), 95.0$ (C-6), 156.3 (C-7), 94.5 (C-8), 156.0 (C-9), 98.7 (C-10), 130.9 (C-1'), 113.9 (C-2'), 144.5 (C-3'), 144.4 (C-4'), 114.5 (C-5'). $118.0\left(\mathrm{C}-6^{\prime}\right)$.

Compound 7 - white amorphous powder; EI-MS $m / z: 290[\mathrm{M}]^{+} ;{ }^{1} \mathrm{H}-\mathrm{NMR}\left(700 \mathrm{MHz}, \mathrm{MeOH}-d_{4}\right): \delta 6.85(1 \mathrm{H}, \mathrm{d}, J=1.9$ $\left.\mathrm{Hz}, \mathrm{H}-2^{\prime}\right), 6.78\left(1 \mathrm{H}, \mathrm{d}, J=8.1 \mathrm{~Hz}, \mathrm{H}-5^{\prime}\right), 6.74\left(1 \mathrm{H}, \mathrm{dd}, J=1.9 \& 8.1 \mathrm{~Hz}, \mathrm{H}-6^{\prime}\right), 5.94(1 \mathrm{H}, \mathrm{d}, J=2.1 \mathrm{~Hz}, \mathrm{H}-6), 5.87(1 \mathrm{H}$, d, $J=2.1 \mathrm{~Hz}, \mathrm{H}-8), 4.58(1 \mathrm{H}, \mathrm{d}, 7.6 \mathrm{~Hz}, \mathrm{H}-2), 3.99(1 \mathrm{H}, \mathrm{m}, \mathrm{H}-3), 2.87(1 \mathrm{H}, \mathrm{dd}, J=7.6$ \& $16.0 \mathrm{~Hz}, \mathrm{H}-4 \mathrm{a}), 2.52(1 \mathrm{H}, \mathrm{dd}$, $J=8.6 \& 16.0 \mathrm{~Hz}, \mathrm{H}-4 \mathrm{~b}) ;{ }^{13} \mathrm{C}-\mathrm{NMR}\left(175 \mathrm{MHz}, \mathrm{MeOH}-d_{4}\right): \delta 81.5(\mathrm{C}-2), 67.4(\mathrm{C}-3), 27.1(\mathrm{C}-4), 156.5(\mathrm{C}-5), 94.9$ (C-6), 156.2 (C-7), 94.1 (C-8), 155.5 (C-9), 94.4 (C-10), 130.8 (C-1'), 113.8 (C-2'), 144.9 (C-3'), 144.8 (C-4'), 114.7 (C-5'), $118.6\left(\mathrm{C}^{-6} \mathbf{6}^{\prime}\right)$.

Compound 8 - white amorphous powder; ESI-MS m/z: $331[\mathrm{M}+\mathrm{H}]^{+} ;{ }^{1} \mathrm{H}-\mathrm{NMR}\left(700 \mathrm{MHz}, \mathrm{MeOH}-d_{4}\right): \delta 6.20(1 \mathrm{H}, \mathrm{d}, J$ $=2.2 \mathrm{~Hz}, \mathrm{H}-4), 5.97(1 \mathrm{H}, \mathrm{d}, J=2.2 \mathrm{~Hz}, \mathrm{H}-6), 5.05(1 \mathrm{H}, \mathrm{d}, J=7.8 \mathrm{~Hz}, \mathrm{H}-1), 2.71(3 \mathrm{H}, \mathrm{s}, \mathrm{H}-8) ;{ }^{13} \mathrm{C}-\mathrm{NMR}(175 \mathrm{MHz}$, $\left.\mathrm{MeOH}-d_{4}\right): \delta 203.4(\mathrm{C}-7), 166.3(\mathrm{C}-1), 164.9(\mathrm{C}-5), 161.2(\mathrm{C}-3), 105.3$ (C-2), 100.6 (C-1'), 96.7 (C-4), 93.9 (C-6), 77.1 (C-5'), 77.0 (C-3'), 73.3 (C-2'), 69.7 (C-4'), 61.0 (C-6'), 32.1 (C-8).

\section{Reagents}

Dulbecco's modified Eagle's medium (DMEM) and fetal bovine serum (FBS) were purchased from Gibco Life Technologies (Rockville, MD, USA). Penicillin-streptomycin was purchased from Invitrogen (Carlsbad, CA, USA). $N$-(1-naphthyl) ethylenediamine dihydrochloride and sulfanilamide were purchased from Merck Millipore (Billerica, MA, USA). Lipopolysaccharide from Escherichia coli serotype 0111:B4, bovine serum albumin, RIPA buffer, protease inhibitor cocktail, Dexamethasone and $N^{\mathrm{G}}$-methyl-1-arginine acetate salt (L-NMMA) were purchased from Sigma Aldrich (St. Louis, MO, USA). Rabbit polyclonal anti-iNOS antibody was purchased from Abcam (Cambridge, UK). Anti- $\beta$-actin, anti-NF-kB p65, anti-NF-kB p50 and rabbit IgG-horseradish peroxidase conjugated secondary antibodies were purchased from Cell Signaling (Danvers, MA, USA). Goat polyclonal anti-Lamin B and goat IgG-horseradish peroxidase conjugated secondary antibodies were purchased from Santa Cruz Biotechnology (Dallas, TX, USA).

\section{Cell culture}

RAW 264.7 mouse macrophage cells (TIB-71) were obtained from the American Type Culture Collection (Manassas, VA, USA). Cells were maintained in DMEM supplemented with 10\% Korean Cell Line Bank were cultured in DMEM supplemented with $10 \%$ FBS and $1 \%$ penicillin $(100 \mathrm{U} / \mathrm{mL})$-streptomycin $(100 \mu \mathrm{g} / \mathrm{mL})$ in a humidified incubator with $5 \% \mathrm{CO}_{2}$ at $37^{\circ} \mathrm{C}$.

\section{Cell viability}

RAW 264.7 cells were seeded on 96 -well plates $\left(5 \times 10^{4}\right.$ cells/well), were treated with $A$. tsao-ko EtOH extracts or either of its main components for $1 \mathrm{~h}$ prior to LPS $(1 \mu \mathrm{g} / \mathrm{mL})$ stimulation for $24 \mathrm{~h}$. MTT solution $(5 \mathrm{mg} / \mathrm{mL})$ was added to each well After $2 \mathrm{~h}$ of incubation at $37^{\circ} \mathrm{C}$ with $5 \% \mathrm{CO}_{2}$, the supernatant was removed and dissolved in DMSO. The absorbance of each well was measured at a wavelength of $540 \mathrm{~nm}$ using a SpectraMax 190PC microplate reader (Molecular Devices, Sunnyvale, CA, USA). Data are presented as the mean \pm standard deviation of three replicates.

\section{Nitric oxide production assay}

RAW 264.7 cells $\left(5 \times 10^{4}\right.$ cells/well in 96 -well plates $)$ were examined with $A$. tsao-ko EtOH extracts or either of its main components for $1 \mathrm{~h}$ prior to LPS $(1 \mu \mathrm{g} / \mathrm{mL})$ stimulation for $24 \mathrm{~h}$. Nitrite in culture medium was measured by using Griess reagent ( $N$-(1-naphthyl) ethylenediamine dihydrochloride and sulfanilamide). Absorbance was subsequently measured at $540 \mathrm{~nm}$, using a SpectraMax 190PC microplate reader (Molecular Devices, Sunnyvale, CA, USA).

\section{Reverse transcription-polymerase chain reaction (RT-PCR)}

RAW 264.7 cells were seeded on 6-well plates $\left(1 \times 10^{6}\right.$ cells/well $)$, were treated with main components $((+)$-epicatechin and (-)-catechin) for $1 \mathrm{~h}$ prior to LPS $(1 \mu \mathrm{g} / \mathrm{mL})$ stimulation for $24 \mathrm{~h}$. The total RNA was extracted using TRIzol ${ }^{\circledR}$ reagent (Invitrogen; Thermo Fisher Scientific, Inc.) according to the manufacturer's protocol. The integrity of the RNA was evaluated using agarose gel electrophoresis and ethidium bromide staining. Briefly, $1 \mu \mathrm{g}$ RNA was used as a template for each RT-PCR, using the SuperScript ${ }^{\circledR}$ III First-Strand Synthesis System and Platinum® PCR SuperMix which contains Taq DNA polymerase (Invitrogen; Thermo Fisher Scientific, Inc.), according to the 
manufacturer's protocol. RT-PCR amplification was performed using MyGene ${ }^{\mathrm{TM}}$ Series Peltier Thermal Cycler (LongGene ${ }^{\circledR}$ Scientific Instruments Co., Ltd., Hangzhou, China) and AccuPower ${ }^{\circledR}$ Pfu PCR PreMix (Bioneer Corporation). The following conditions were used for each PCR reaction: $95^{\circ} \mathrm{C}$ for 5 min $(1 \mathrm{cycle})$; $95^{\circ} \mathrm{C}$ for $30 \mathrm{sec}$, $55^{\circ} \mathrm{C}$ for $40 \mathrm{sec}$, and $72^{\circ} \mathrm{C}$ for $1 \mathrm{~min}(30 \mathrm{cycles})$; and a final extension phase at $72^{\circ} \mathrm{C}$ for $10 \mathrm{~min}$. The following primers (Bioneer Corporation, Daejeon, Republic of Korea) were used for PCR amplification: TNF- $\alpha$, 5'-CTGAGA CAATGAACGCTACA-3' (sense) and 5'-TTCTTCCACATCTATGCCAC-3' (antisense); IL-1 3 , 5' -CTTTGAAGAAGAGCCCATCC-3' (sense) and 5'-TTTGTCGTTGCTTGGTTCTC-3' (antisens e); IL-10, 5'-CCTGGTAGAAGTGATGCCCCAGGCA-3' (sense) and 5'- CTATGCAGTTGATGA AGATGTCAAA-3' (antisense); glyceraldehyde-3-phosphate dehydrogenase (GAPDH), 5'-CAG GTACCAGGAGAGTG-3' (sense) and 5'-GTAGACTCCACGACATCTC-3' (antisense). PCR pro ducts were electrophoresed on a 1\% agarose gel and stained with ethidium bromide. Bands were captured using a ChemiDoc ${ }^{\mathrm{TM}}$ XRS system (Bio-Rad Laboratories) and quantified using Quantity One software version 4.6.3 (Bio-Rad Laboratories). Data was compared with the housekeeping gene GAPDH.

\section{Enzyme-linked immunosorbent assay (ELISA)}

RAW 264.7 cells $\left(1 \times 10^{6}\right.$ cells/well in 6-well plates) were examined with main components $((+)$-epicatechin and (-)-catechin) for $1 \mathrm{~h}$ prior to LPS $(1 \mu \mathrm{g} / \mathrm{mL})$ stimulation for $24 \mathrm{~h}$. Levels of TNF- $\alpha$, IL-1 $\beta$, and IL-10 in cell culture supernatants were quantified using platinum TNF- $\alpha$, IL-1 $\beta$, and IL-10 ELISA kits (eBioscience, Inc., San Diago, CA, USA), according to the manufacturer's instructions.

\section{Western blot analysis}

Following treatment as indicated, cells were washed twice with PBS and lysed with RIPA buffer containing protease inhibitor cocktails. Cell lysates were clarified at $13,000 \times \mathrm{g}$ for $10 \mathrm{~min}$ at $4{ }^{\circ} \mathrm{C}$, and the supernatants were subjected to Western blot analysis as described previously. All western blot analyses are representative of at least three independent experiments.

\section{Preparation of nuclear extract}

RAW 264.7 cells were plated at a density of $1 \times 10^{6}$ cells/well in 6-well plates and treated with main components ((+)-epicatechin and (-)-catechin) for $1 \mathrm{~h}$ prior to LPS $(1 \mu \mathrm{g} / \mathrm{mL})$ stimulation for $30 \mathrm{~min}$. cells were washed twice with ice-cold PBS prior to trypsinization and centrifugation at $90 \mathrm{x} \mathrm{g}$ and $4^{\circ} \mathrm{C}$ for 5 min. Cells were then centrifuged at 20,000 $\mathrm{x} \mathrm{g}$ and $4^{\circ} \mathrm{C}$ for $5 \mathrm{~min}$ and resuspended in $200 \mu \mathrm{l}$ buffer $(10 \mathrm{mM} \mathrm{HEPES}$ at $\mathrm{pH} 7.9,10 \mathrm{mM} \mathrm{KCl,} 1$ $\mathrm{mM}$ DTT, $0.5 \mathrm{mM}$ PMSF and $0.1 \mathrm{mM}$ EDTA). After incubation on ice for $10 \mathrm{~min}$, cells were lysed by the addition of $12.5 \mu \mathrm{l}$ of $10 \% \mathrm{NP}-40$. Cells were then centrifuged at $20,000 \times \mathrm{g}$ for $2 \mathrm{~min}$ at $4^{\circ} \mathrm{C}$, and the supernatants were collected as cytosolic extract. Pellets were resuspended in $50 \mu \mathrm{l}$ of extraction buffer $(20 \mathrm{mM}$ HEPES at pH 7.9, $0.4 \mathrm{M} \mathrm{NaCl}, 1$ mM DTT, $1 \mathrm{mM}$ PMSF, $1 \mathrm{mM}$ EDTA and 1\% NP-40) and incubated on ice for $10 \mathrm{~min}$. Nuclear extract was collected by centrifugation at $15,000 \times \mathrm{g}$ for $15 \mathrm{~min}$ at $4^{\circ} \mathrm{C}$.

\section{Statistical analysis}

Statistical analysis was performed by a Student's t-test using Microsoft Excel 2007 software (Microsoft Corporation, Redmond, WA, USA). Results are presented as the mean \pm standard deviation. $\mathrm{P}<0.05$ was considered to indicate a statistically significant difference.

\section{Results}

LPS, a component of the cell wall of gram-negative bacteria, increases the levels of pro-inflammatory cytokines, including NO, TNF- $\alpha$, IL-10, and IL-1 $\beta$, in macrophages and monocytes. It also induces diverse disease-related inflammatory responses (Willeaume et al. 1995). As shown in Table 1, we showed that $80 \%$ EtOH extract of the powdered fruit of A. tsao-ko decreased LPS-induced NO production in RAW 264.7 cells.

Table 1: Inhibitory effects of A. tsao-ko extract and isolated fractions on LPS-induced NO production RAW 264.7 cells

\begin{tabular}{ccc}
\hline \hline Fractions & $\mathrm{NO} \mathrm{IC}_{50}(\mu \mathrm{g} / \mathrm{mL})$ & $\mathrm{MTT} \mathrm{IC}_{50}(\mu \mathrm{g} / \mathrm{mL})$ \\
\hline $80 \%$ EtOH ext. & $59.5 \pm 1.8^{\mathrm{a}}$ & $>100$ \\
$\mathrm{CH}_{2} \mathrm{Cl}_{2}$ & $<25$ & $92.8 \pm 1.6$ \\
EtOAc & $<25$ & $>100$ \\
\hline \hline
\end{tabular}




\begin{tabular}{ccc}
\hline \hline $\mathrm{BuOH}$ & $73.1 \pm 3.3$ & $>100$ \\
$\mathrm{H}_{2} \mathrm{O}$ & $>25$ & $>100$ \\
$\mathrm{PC}^{\mathrm{b}}$ & $27.3 \pm 0.3 \mu \mathrm{M}$ & $>100$ \\
\hline \hline${ }^{\mathrm{a}}$ The experiments were repeated in triplicate; values are expressed as mean \pm SD. & ${ }^{b} N$-Monomethyl-L-arginine
\end{tabular}
(LNMMA) was used as a positive control.

The concentration of extract required for $50 \%$ inhibition $\left(\mathrm{IC}_{50}\right)$ of activity was $59.5 \mu \mathrm{g} / \mathrm{mL}$. Among the four fractions obtained by serial solvent partition of A. tsao-ko $\left(\mathrm{CH}_{2} \mathrm{Cl}_{2}\right.$ soluble fraction, EtOAc soluble fraction, $\mathrm{n}-\mathrm{BuOH}$ soluble fraction, and remaining aqueous fraction), the $\mathrm{CH}_{2} \mathrm{Cl}_{2}$ and the EtOAc soluble fraction displayed potent inhibitory activity $\left(\mathrm{IC}_{50}<25 \mu \mathrm{g} / \mathrm{mL}\right.$ ). The concentration of $A$. tsao-ko Ext. and the four fractions that is possibly cytotoxic to RAW 264.7 cells was determined by MTT assay. Cytotoxicity effect was not caused by $\mathrm{CH}_{2} \mathrm{Cl}_{2}$ soluble fraction, EtOAc soluble fraction, $n$-BuOH soluble fraction, and aqueous fraction in LPS-induced RAW 264.7 cells. Therefore, bioassay guided purification of the active fraction, i.e., the EtOAc soluble fraction of A. tsao-ko, was conducted to purify the active components that display anti-inflammatory activity against LPS-treated RAW 264.7 cells.

Repeated column chromatography on silica gel and a RP-18 column of the EtOAc soluble fraction led to the isolation of eight compounds: 4-hydroxy-3-methoxy-benzoic acid (1) (Gonzalez-Baro 2008), meso-hannokinol (2) (Lee et al. 2008), (+)-hannokinol (3) (Lee et al. 2008), coumaric acid (4) (Salum et al. 2010), 4-hydroxy-benzoic acid (5) (Sivakumar et al. 2010), (+)-epicatechin (6) (Teresita et al. 2000), (-)-catechin (7) (Teresita et al. 2000), and myrciaphenone A (8) (Gupte 2009) (Fig. 1).<smiles>[R]c1ccc(O)c([R2])c1</smiles>

1. 4-hydroxy-3-methoxy-benzoic acid

$$
\mathrm{R}_{1}: \mathrm{COOH}, \quad \mathrm{R}_{2}: \mathrm{OCH}_{3}
$$

4. coumaric acid

$$
\mathrm{R}_{1}: \mathrm{CH}=\mathrm{CHCOOH}, \quad \mathrm{R}_{2}: \mathrm{H}
$$

5. 4-hydroxy-benzoic acid

$$
\mathrm{R}_{1}: \mathrm{COOH}
$$$$
\mathrm{R}_{2}: \mathrm{H}
$$<smiles>Oc1ccc(CC[C@H](O)C[C@H](O)CCc2ccc(O)cc2)cc1</smiles><smiles>Oc1ccc(CC[C@H](O)C[C@H](O)CCc2ccc(O)cc2)cc1</smiles><smiles>[R]C1Cc2c(O)cc(O)cc2OC1c1ccc(O)c(O)c1</smiles>

6. (+)-epicatechin, $\mathrm{R}=\beta-\mathrm{OH}$

7. (-)-catechin, $\quad \mathrm{R}=\alpha-\mathrm{OH}$<smiles>CC(=O)c1c(O)cc(O)cc1OC(O)C(O)C(O)CO</smiles>

8. myrciaphenone A

Figure 1: Structures of compounds isolated from the EtOAc fraction (1-8)

NMR and mass spectra were analyzed to determine the structures of the compounds. In addition, all physical and spectroscopic data obtained in the present study were compared with those of previously published manuscripts. Isolated components were tested for their inhibitory effect on NO production in LPS-stimulated RAW 264.7 cell culture system.

Among the isolated compounds, compounds $6((+)$-epicatechin) and 7 ((-)-catechin) showed the highest activity (IC 50 $=70.6 \mu \mathrm{M}$ and $\mathrm{IC}_{50}=73.3 \mu \mathrm{M}$, respectively) against NO production without cytotoxicity (Table 2, Fig. 2). 
Table 2: Inhibitory effect of compounds 1-5 on LPS-induced NO production RAW 264.7 cells

\begin{tabular}{cll}
\hline \hline Compounds & $\mathrm{IC}_{50}$ value $(\mu \mathrm{M})$ & MTT assay $\mathrm{IC}_{50}(\mu \mathrm{M})$ \\
\hline 1 & $>100^{\mathrm{a}}$ & $>100$ \\
2 & $>100$ & $>100$ \\
3 & $>100$ & $>100$ \\
4 & $>100$ & $>100$ \\
5 & $>100$ & $>100$ \\
6 & $70.57 \pm 0.3$ & $>100$ \\
7 & $73.32 \pm 0.5$ & $>100$ \\
8 & $>100$ & $>100$ \\
PC $^{\mathrm{b}}$ & $25.29 \pm 0.4$ & $\mathrm{P}$
\end{tabular}

${ }^{\mathrm{a}}$ The experiments were repeated in triplicate; values are expressed as mean $\pm \mathrm{SD}$.

${ }^{\mathrm{b}} \mathrm{N}$-Monomethyl-L-arginine (LNMMA) was used as a positive control.

A.
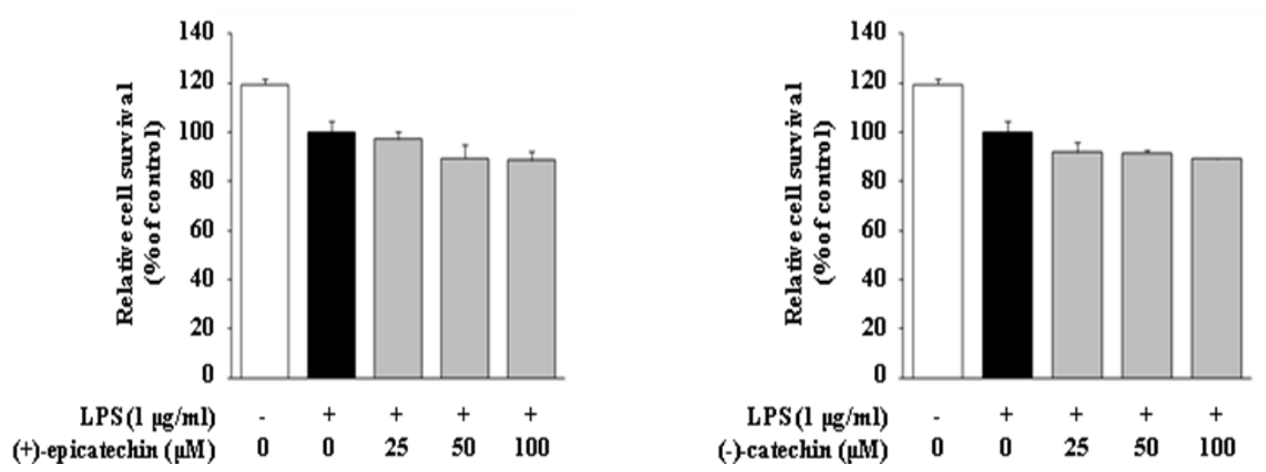

B.
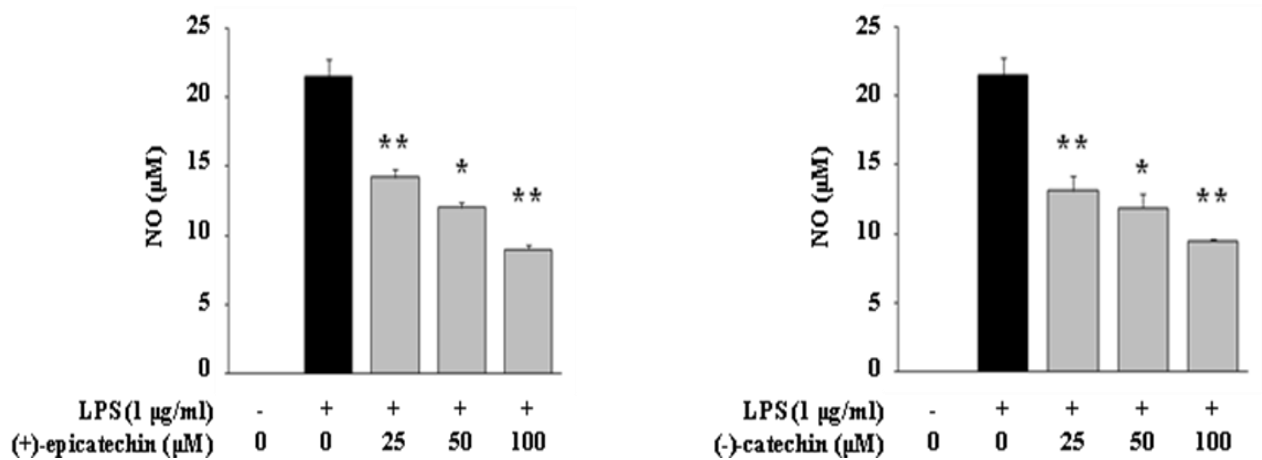

Figure 2: Effect of (+)-epicatechin (6) and (-)-catechin (7) on cytotoxicity and inhibition of NO production in RAW 264.7 macrophages. Cells were examined with (+)-epicatechin and (-)-catechin for $1 \mathrm{~h}$ prior to LPS (1 $\mu \mathrm{g} / \mathrm{mL})$ stimulation for $24 \mathrm{~h}$. A. Cytotoxicity of (+)-epicatechin and (-)-catechin was determined by MTT assay. B. NO production was determined by measuring the concentrations of $\mathrm{NO}_{2}{ }^{-}$and $\mathrm{NO}_{3}{ }^{-}$in cell culture supernatants. The bars represent the mean $\pm \mathrm{SD}$ of three independent experiments. Statistical significance is indicated $(* P<0.05, * * P<0.01$, compared with LPS-treated cells).

Constantly, we conducted the effect of (+)-epicatechin and (-)-catechin on iNOS expression induced by LPS using western blot analysis. As shown in Fig. 3, (+)-epicatechin and (-)-catechin effectively inhibited LPS-induced expression of iNOS at protein level in RAW264.7 cells.

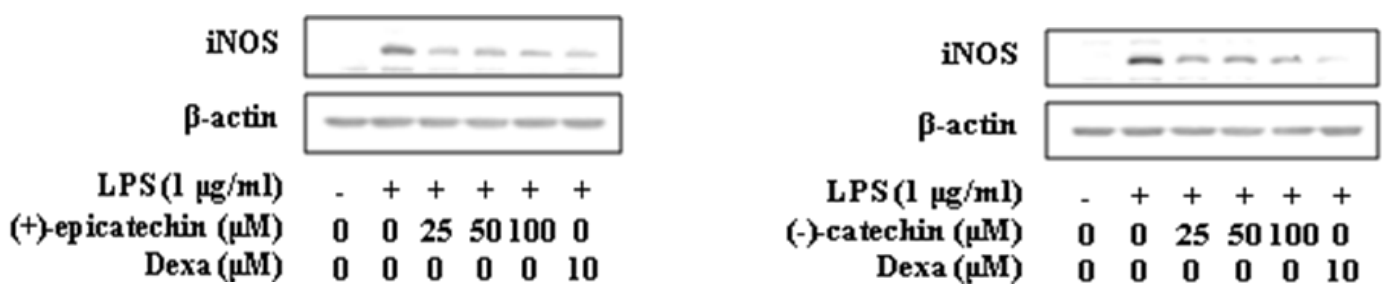

Figure 3: Effect of (+)-epicatechin and (-)-catechin on the expression of iNOS in LPS-stimulated RAW 264.7 cells Expression levels of iNOS protein were determined by western blot. $\beta$-actin served as internal control western blot. Values represent the mean \pm SD of three independent replicates. 
These results indicate that treated with (+)-epicatechin and (-)-catechin $(25-100 \mu \mathrm{M})$ significantly suppress LPS-induced NO production related to down-regulating iNOS expression in RAW264.7 macrophages. NF- $\kappa \mathrm{B}$ plays a crucial role in general inflammatory reaction by controlling the activation of iNOS. The activation of NF- $\kappa \mathrm{B}$ caused translocation of active NF- $\mathrm{BB}$ p50 and p65 from the cytoplasm to nucleus (Chen et al. 1995). In this study, we investigated whether (+)-epicatechin and (-)-catechin could suppress the translocation of NF- $\kappa B$ (p65 and p50) into the nucleus. We showed that (+)-epicatechin and (-)-catechin inhibited the translocation of NF- $\kappa \mathrm{B}$ (p65 and p50) into the nucleus (Fig. 4).
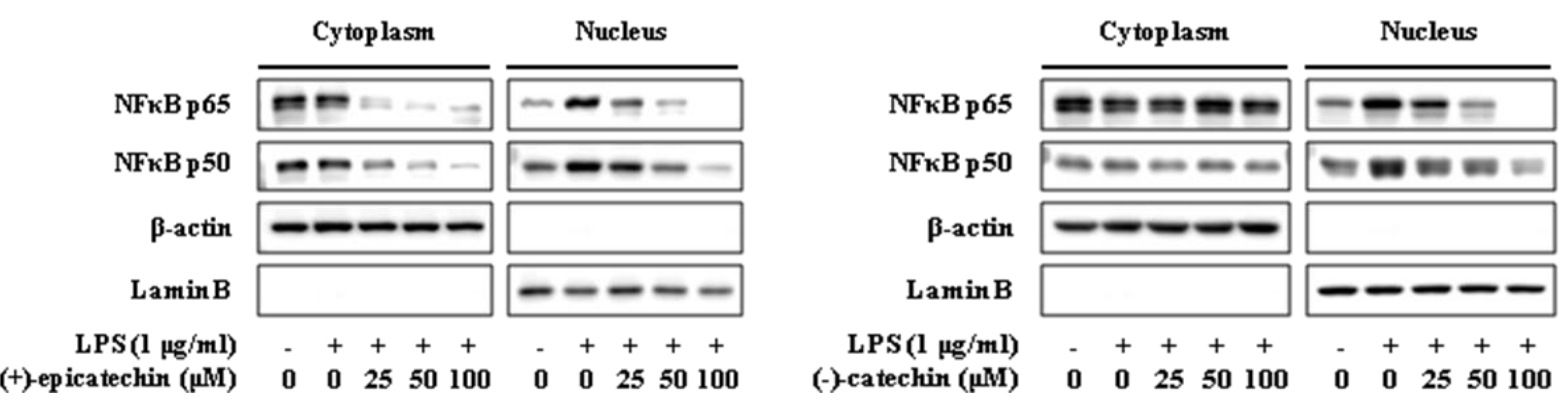

Figure 4: Regulatory effects of (+)-epicatechin and (-)-catechin on NF-kB nuclear localization in LPS-stimulated RAW 264.7 cells. Cells were pretreated with (+)-epicatechin and (-)-catechin for $1 \mathrm{~h}$, followed by LPS (1 $\mu \mathrm{g} / \mathrm{mL})$ stimulation for $30 \mathrm{~min}$. Cytosolic and nuclear extracts were analyzed via western blot with anti-NF- $\kappa \mathrm{B}$ p65, anti-NF- $\mathrm{B}$ p50, anti- $\beta$-actin or anti-Lamin B antibodies. $\beta$-actin served as a marker for the cytoplasm and Lamin B for the nucleus. Results shown are representative of at least three independent experiments.

Next, we examined the effect of (+)-epicatechin and (-)-catechin on inflammatory cytokines, such as TNF- $\alpha$, IL-1 $\beta$, and IL-10 in LPS-stimulated RAW 264.7 cells. In this study, we measured the expression levels of these inflammatory cytokines by RT-PCR and ELISA analysis. As shown in Fig. 5, (+)-epicatechin and (-)-catechin inhibited the expression of TNF- $\alpha$, IL-1 $\beta$, and IL-10 in a dose-dependent manner at both the mRNA and protein levels in RAW264.7 cells. These results showed that (+)-epicatechin and (-)-catechin have a potential activity on anti-inflammatory activity through the down-regulation of the NF- $\mathrm{B}$ signaling pathway.

A.

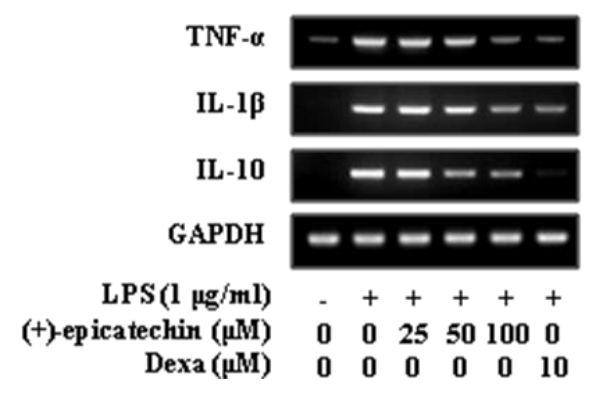

B.

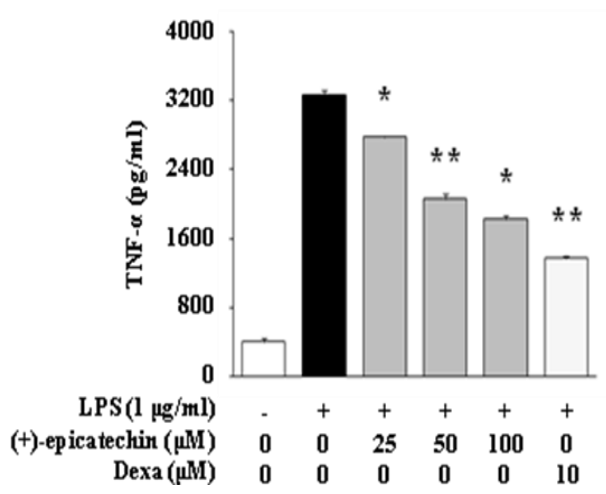

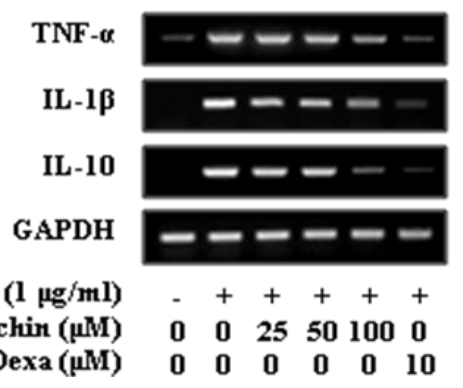

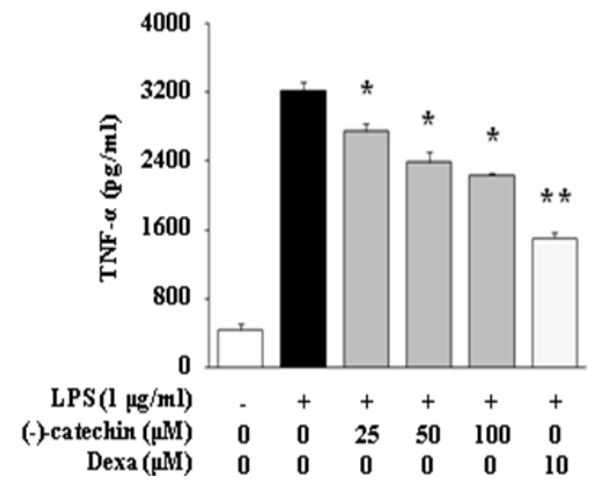



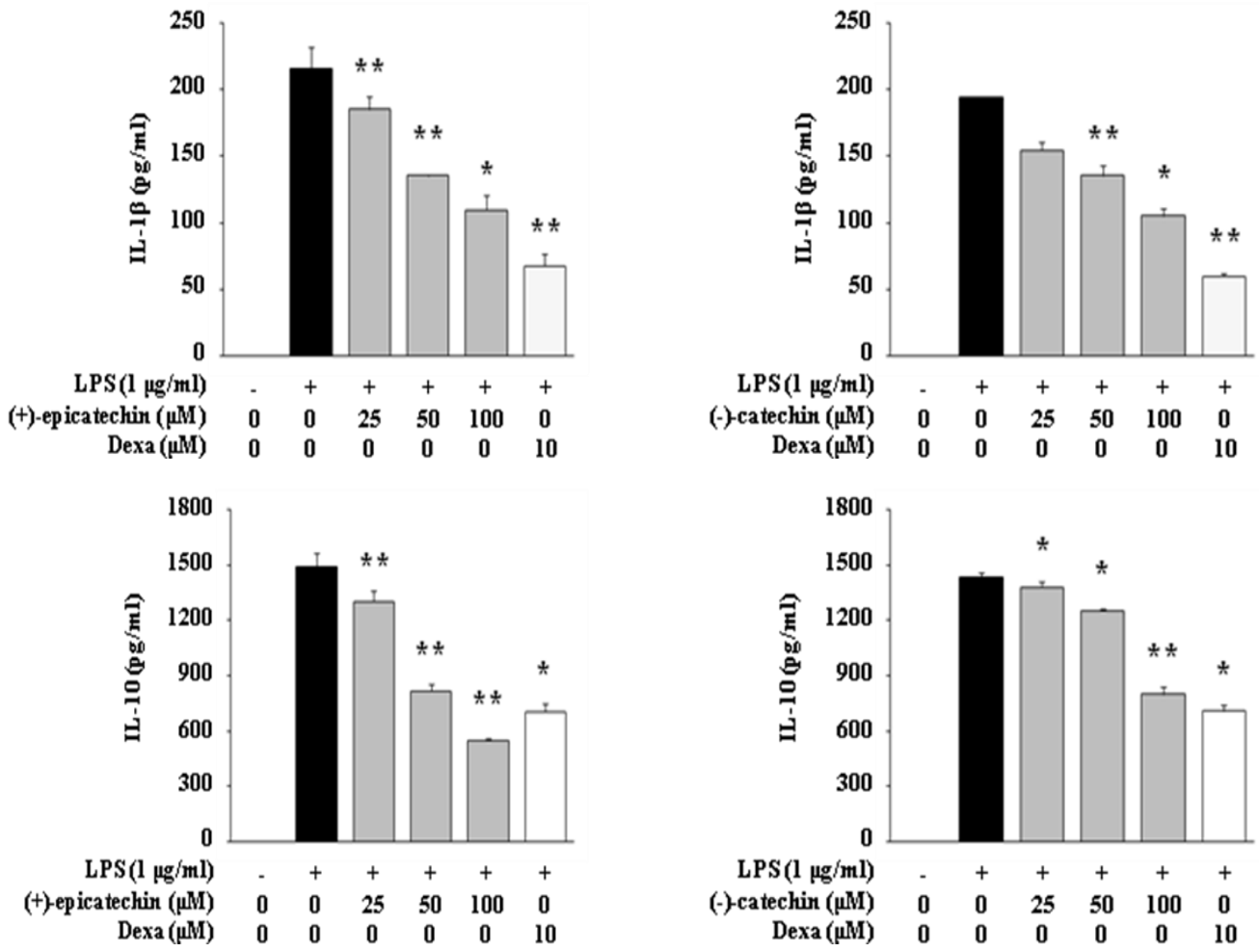

Figure 5: Effects of (+)-epicatechin and (-)-catechin on the expression and secretion of various cytokines in RAW 264.7 cells. A. The expression of TNF- $\alpha$, IL-1 $\beta$, and IL-10 mRNA was determined by RT-PCR analysis. B. Cell culture supernatant was subjected to TNF- $\alpha$, IL-1 $\beta$, and IL-10 cytokine ELISA as described in Materials and methods. Values represent the mean $\pm \mathrm{SD}$ of three independent experiments. Statistical significance is indicated $(* P<0.05, * * P<0.01$, compared with LPS-treated cells).

\section{Discussion}

Macrophages play an important role in both passive and active immunity and regulate anti-inflammatory mediators including NO and pro-inflammatory cytokines (Alleva et al., 2002; Eliopoulos et al., 2002). iNOS (NOS II), one of the isoforms of the nitric oxide synthase (NOS) family, is found in macrophages and hepatocytes. iNOS is not expressed in most resting cells; however, upon exposure to endogenous and exogenous stimulators, such as LPS or pro-inflammatory cytokines like TNF- $\alpha$, IL-1 $\beta$ and IL-10 the expression of the iNOS gene is increased and triggers several disadvantageous cellular responses, causing diseases, including inflammation, sepsis, and stroke (Nathan et al., 1992; Marletta et al., 1993; Duval et al., 1996). In order to extend the understanding of the anti-inflammatory effects of (+)-epicatechin and (-)-catechin, which showed the potent inhibitory activity, on the expression of inflammatory proteins, iNOS expression and the production of NO were evaluated in LPS-stimulated RAW 264.7 cells. Treatment with (+)-epicatechin and (-)-catechin inhibited NO production and iNOS expression in a dose-dependent manner in LPS-stimulated RAW 264.7 cells (Fig. 3). TNF- $\alpha$ is an element of the innate immune response against stimulus and IL-1 $\beta$ is an important factor in the acute inflammation response (Strandberg et al., 2005). NF- $\kappa \mathrm{B}$ activation leads to release of pro-inflammatory proteins production. $\mathrm{NF}-\kappa \mathrm{B}$ transcription factors are in the cytoplasm as an inactive state and when stimulation, NF- $\mathrm{KB}$ transfer to nuclear localization (Wu et al., 2008).

Altogether, the results indicated that (+)-epicatechin and (-)-catechin, isolated from A. tsao-ko, effectively inhibited NO production in LPS-stimulated RAW 264.7 cells by suppression of iNOS expression and the production of inflammatory cytokines, such as TNF- $\alpha$, IL-1 $\beta$ and IL-10. In addition, we confirmed that (+)-epicatechin and (-)-catechin have anti-inflammatory activity via down-regulating nuclear localization of NF- $\mathrm{kB}$.

\section{Acknowledgment}

This work was supported by a grant from the Next-Generation BioGreen 21 Program (No. PJ01119301), Rural Development Administration, Republic of Korea.

Conflict of Interest: Authors have declared that no competing interests exist. 


\section{References}

1. Alleva DG, John EB, Lio FM, Boehme SA, Conlon PJ, Crowe PD (2002) Regulation of murine macrophage pro-inflammatory and anti-inflammatory cytokines by ligands for peroxisome proliferator-activated receptor-gamma: counter-regulatory activity by IFN-gamma. J Leukoc Biol., 71(4):677-685.

2. Chen Z, Hagler J, Palombella VJ, Melandri F, Scherer C, Ballard D, Maniatis T (1995) Signal-induced site-specific phosphorylation targets I kappa B alpha to the ubiquitin-proteasome pathway. Genes Dev., 9(13):1586-1597.

3. Dawson VL, Brahmbhatt HP, Mong JA, Dawson TM (1994) Expression of inducible nitric oxide synthase causes delayed neurotoxicity in primary mixed neuronal-glial cortical cultures. Neuropharmacology, 33:1425-1430.

4. Donga H, Goua YL, Caob SG, Chena SX, Simb KY, Gohb SH, Kini RM (1988) Eicosenones and methylated flavonols from Amomum koenigii. Phytochemistry, 50:899-902.

5. Duval DL, Miller DR, Collier J, Billings RE (1996) Characterization of hepatic nitric oxide synthase: identification as the cytokine-inducible form primarily regulated by oxidants. Mol Pharmacol., 50:277-284.

6. Eliopoulos AG, Dumitru CD, Wang CC, Cho J, Tsichlis PN (2002) Induction of COX-2 by LPS in macrophages is regulated by Tpl2-dependent CREB activation signals. EMBO J., 21(18):4831-4840.

7. Gonzalez-Baro, AC (2008) Theoretical and spectroscopic study of vanillic acid. J Molecular Structure., 889:1-3.

8. Gupte A (2009) Synthesis and biological evaluation of phloridzin analogs as human concentrative nucleoside transporter 3 (hCNT3) inhibitors. Bioorg Med Chem Lett., 19:917-921.

9. Kamchonwongpaisan S, Nilanonta C, Tarnchompoo B, Thebtaranonth C, Thebtaranonth Y, Yuthavong Y, Kongsaeree P, Clardy J (1995) An antimalarial peroxide from Amomum krervanh Pierre. Tetrahedron Let.,t 36:1821-1824.

10. Lee JY, Kim SH, Sung SH, Kim YC (2008) Inhibitory constituents of lipopolysaccharide -induced nitric oxide production in BV2 microglia isolated from Amomum tsao-ko. Planta Med., 74: 867-869.

11. Lim TK (2013) Edible Medicinal and Non-Medicinal Plants (Vol 5). Springer, Las Vegas, NV.

12. Marletta MA (1993) Nitric oxide synthase structure and mechanism. J Biol Chem., 268:12231-12234.

13. Moon SS, Lee JY, Cho SC (2004) Isotsaokoin, an antifungal agent from Amomum tsao-ko. J Nat Prod., 67:889-891.

14. Nathan C (1992) Nitric oxide as a secretory product of mammalian cells. FASEB J., 6:3051-3064.

15. Salum ML (2010) Photoisomerization of ionic liquid ammonium cinnamates: one-pot synthesis-isolation of Zcinnamic acids. Organic Lett., 12:4808-4811.

16. Sivakumar S (2010) Synthesis and crystal structures of lanthanide 4-benzyloxy benzoates: influence of electronwithdrawing and electron-donating groups on luminescent properties. Dalton Transactions, 39:776-786.

17. Strandberg Y, Gray C, Vuocolo T, Donaldson L, Broadway M, Tellam R (2005) Lipopolysaccharide and lipoteichoic acid induce different innate immune responses in bovine mammary epithelial cells. Cytokine, 31(1):72-86.

18. Teresita SM, Hiroe K, Masashi H, Nobuji N (2000) Constituents of Amomum tsao-ko and their radical scavenging and antioxidant activities. JAOCS, 77:667-673.

19. Willeaume V, Kruys V, Mijatovic T, Huez G (1995) Tumor necrosis factor-alpha production induced by viruses and by lipopolysaccharides in macrophages: similarities and differences. J Inflamm., 46:1-12.

20. Wu W, Alexis NE, Chen X, Bromberg PA, Peden DB (2008) Involvement of mitogen-activated protein kinases and NFkappaB in LPS-induced CD40 expression on human monocytic cells. Toxicol Appl Pharmacol., 228:135-143.

21. Zhao ZZ, Xiao PG (2010) Encyclopedia of Medicinal Plants. (Vol 4). World Publishing Corporation, Hong kong: 36-38. 